\title{
INDEKS MENTAL-KOGNITIF ISLAM REMAJA BERISIKO: SATU KAJIAN PENDEKATAN PSIKORELIGIO KELUARGA ISLAM DI MALAYSIA
}

\author{
${ }^{1}$ Khairil Anwar \\ ${ }^{2}$ Khaidzir Hj. Ismail \\ ${ }^{1}$ Sri Wahyuni \\ ${ }^{1}$ Fakultas Psikologi, Universitas Islam Negeri Sultan Syarif Kasim Riau, \\ Indonesia \\ ${ }^{2}$ School of Psychology \& Human Development, Faculty of Social Sciences \\ and Humanities, Universiti Kebangsaan
}

\begin{abstract}
This working paper is to explain the risk of adolescent-cognitive mental index of Islam and this work paper also aims as the basis for the establishment of the Islamic family law. Islamic mentalities which are termed as an internal structure of human beings that give birth to perception, introspection, memory, creativity, imagination, conception, belief, reasoning, will, and emotion as a unified way of thinking based on Islam. This concept is expected to predict and have implications for family resilience in the context of welfare psychology of families, which will further be able to resolve various cases that afflict Muslim communities in general and Muslim families in particular. Six rehabilitation centers in Malaysia were selected for this study involving as many as 490 adolescents involved with legal violations and 128 students from one high school as a comparison group. The background of the economic status of the respondent's family was also examined and data collection was carried out using psychological instruments, the Islamic mental-cognitive scale. Data were analyzed using mathematical formulas to form an Islamic mental-cognitive index consisting of several domains. The results show that the Islamic mental-cognitive index of adolescents is at risk of being at a low stage (score 51.56). the results of this study are planned to create an intervention module and Islamic mental-cognitive prevention for risky adolescents especially and Muslim adolescents in general
\end{abstract}

Keywords: mental-cognitive, Islam adolescent, psychoreligion, Malaysia

\begin{abstract}
Abstrak
Kertas kerja ini adalah untuk menjelaskan indeks mental-kognitif Islam remaja berisiko dan kertas kerja ini juga bertujuan sebagai dasar pembentukan sahsiah keluarga Islam. Mental-kognitif Islam yang diistilahkan sebagai suatu struktur internal manusia yang melahirkan persepsi, introspeksi, memori, kreativitas, imaginasi, konsepsi, keyakinan, penalaran, kemauan, dan emosi sebagai suatu kesatuan cara berfikir yang berasaskan Islam. Konsep ini diharapkan dapat memprediksi dan berimplikasi terhdap ketahanan keluarga dalam konteks kesejahteraan
\end{abstract}


psikologi keluaraga, yang lebih jauh akan dapat menyelesaikan berbagai kasus yang menimpa masyarakat muslim pada umumnya dan keluarga muslim pada khususnya. Enam pusat rehabilitasi di Malaysia telah dipilih untuk penelitian ini dengan melibatkan sebanyak 490 orang remaja yang terlibat dengan pelanggaran hukum dan 128 pelajar dari satu sekolah menengah atas sebagai kelompok pembanding. Latarbelakang status ekonomi keluarga responden juga diteliti dan pengumpulan data dilakukan menggunakan instrumen psikologi, skala mental-kognitif Islam. Data dianalisis menggunakan formula matematika untuk membentuk indeks mental-kognitif Islam yang terdiri dari beberapa domain. Hasil menunjukkan indeks mental-kognitif Islam remaja berisiko berada pada tahap yang rendah. Hasil penelitian ini direncanakan untuk penciptakan satu modul intervensi dan prevensi mental-kognitif Islam untuk remaja berisiko khususnya dan remaja muslim pada umumnya.

Kata kunci: mental-kognitif, remaja Islam, psikoreligio, Malaysia

\section{PENDAHULUAN}

Generasi muda masa kini tidak terlepas daripada berhadapan dengan pelbagai bentuk cabaran yang akan mencabar kemampuan dan ketahanan mereka (Zainah et al., 2013; Jamie, 2011). Malah, liputan meluas di media massa berkaitan isu gejala social yang melibatkan pelajar sekolah sedikit sebanyak telah mempengaruhi pemikiran masyarakat untuk menganggap golongan ini sebagai liabiliti berbanding aset kepada negara. Ini karena, beberapa faktor seperti sistem kekeluargaan, sistem pendidikan, daya tahan pelajar yang rendah, dan pengaruh media diambil kira oleh masyarakat (Kementerian Belia dan Sukan, 2015). Justru, dalam membangunkan pelajar yang berdayatahan serta mempraktikkan gaya hidup yang sihat, kesihatan fizikal, mental, sosial, dan spiritu alamat ditekankan. Kesihatan fizikal merujuk kepada kesihatan tubuh badan. Kesihatan mental adalah melalui pembinaan tingkah laku berdayatahan. Kesihatan social pula menerusi pendidikan yang dapat membentuk individu yang bertanggung jawab terhadap diri, keluarga, dan masyarakat. Manakala, kesihatan spiritual adalah dengan menerapkan pengukuhan nilai agama dalam diri anak-anak dan pelajar sejak kecil, yang mana ibu bapa turut memainkan peranan penting dalam koteks ini (Kementerian Pelajaran dan Sukan, 2015). Secara ringkasnya, dapat diperhatikan bahawa antara aspek yang perlu ditekankan dalam menghasilkan pelajar yang berkualiti ialah aspek daya tahan dan kefungsian sesebuah keluarga. 


\section{Mental-Kognitif Islam}

Dalam banyak literatur, sering menyamakan makna antara mental dan kognitif. Kedua konsep ini selalu dimaksudkan dengan arti berfikir. Penyamaan makna kedua konsep ini tidak diketepikan, kerana memang keduanya merujuk kepada proses manusia berfikir. Lebih jauh apabila kedua konsep ini ditelusuri secara mendalam, maka didapati titik perbedaan untuk menerangkan proses manusia berfikir.

Kognitif secara umum adalah suatu proses yang lebih mengarah kepada proses penemuan suatu maklum atau pengenalan kembali suatu maklumat. Dalam erti kata lain kognitif adalah suatu proses kemampuan manusia berfikir untuk mengenali dan menemukan maklumat sama ada yang bersumber daripada dalaman manusia mahupun yang bersumber daripada luaran manusia atau faktor persekitaran. Manakala mental adalah motor penggerak dan abstraksi dari proses kognitif yang menghubungkan pola-pola berfikir dengan alam kesedaran manusia, di mana manusia sedar bahawa sedang terjadi proses berfikir yang pada akhirnya kegiatan mental inilah yang akan menjadi titik utama dalam penyelesaian masalah. Jadi dapat dikatakan bahawa mental kognitif adalah proses kecerdasan seseorang menangani masalah dari input-input luaran dan dalaman manusia.

Sebagai perbandingan dapat dirujuk dari teori Cattel (1963) mengenai organisasi mental, beliau mengklasifikasi kemampuan mental kepada dua jenis, iaitu intelegensi fluid yang merupakan factor semula jadi biological manakala kecerdasan crystallized yang mereflaksikan adanya pengaruh pengalaman, pendidikan, budaya dan kebiasaan dalam diri seseorang individu.

Berdasarkan teori Cattel ini berkemungkinan dapat dianalogikan proses mental kognitif adalah berlangsung dari dua jenis kemampuan mental di atas. Ertinya secara semula (fluid) jadi setiap orang telah membawa potensi mental kognitif untuk memproses cara berfikirnya, manakala kualiti mental kognitif bergantung kepada persekitaran (crystallized). Tahap Mental kognitif yang baik akan mempengaruhi cara seseorang individu untuk dapat memahami dan menyelesaikan masalah dengan baik.Seiring dengan ini, Mohammad Saleh (2007) menggambarkan bahawa kemampuan kognitif seseorang yang beramal dengan ikhlas, sangat berpengaruh terhadap pola coping seseorang individu untuk menyelesaikan sesuatu masalah.

Dengan demikian menurut Saifuddin Azwar (1996) intelegensi crystallized dapat dipandang sebagai intipati pengalaman yang terjadi sewaktu intelegensi fluid bercampur dengan apa yang disebut intelegensi budaya. Intellegensi crystallized akan meningkat dalamdiri seseorang, seiring dengan bertambahnya pengalaman. Dengan kata lain, tugas tugas kognitif adalah sebagai keterampilan dan kebiasan yang telah mengkristal akibat pengalaman sebelumnya, seperti banyaknya 
menguasai kosakata, pengetahuan, kebiasaan penalaran dan pelbagai hal yang berhubungan dengan semua yang akan meningkatkan intelegensi dimaksudkan.

Pemahaman mental kognitif dari teori Cattel diatas, membawa sebuah implikasi yang positif terhadap mengkristalnya mental kognitif dalam menyelesaikan masalah, disamping memberi pengaruh besar terhadap pengetahuan dan pengalaman keagamaan.

Dengan demikian Mental Kognitif Islam dapat dikatakan sebagai istilah khusus yang digunakan untuk melihat pola-pola dan cara berfikir seseorang individu tentang kualitas pengetahuan, pemahaman dan pengamalan tentang keIslaman, atau dapat juga dikatakan mental kognitif Islam adalah cara berfikir umat Islam dalam memandang diri dan persekitarannya.

Oleh itu, dari definisi kognitif dan definisi mental yang diterokai, maka istilah Mental- Kognitif Islam definisinya adalah suatu struktur dalaman manusia yang melahirkan persepsi, introspeksi, memori, kreativiti, imaginasi, konsepsi, keyakinan, penalaran, kemauan, dan emosi sebagai suatu kesatuan cara berfikir yang berteraskan Islam. Untuk mengukur tahap mental kognitif Islam remaja yang melakukan salah laku, maka istilah ini dioperasionalkan dari domain-domain yang diambil konstruknya dari ajaran Islam, seperti berikut ini:

Pertama: Ilmu Ketauhidan yang dibentuk dari konstruk rukun iman, hakikat yang pertama, Keesaan yang mutlak, kesempurnaan tertinggi Qada dan Qadar, amal sendi keimanan, iman dan dosa, pertikaian, Nubuwah, kekekalan atau keabadian, tauhid merupakan tapak kebahagiaan, tauhid merupakan tapak bagi akhlak yang mulia, tauhid merupakan tapak bagi ketenangan jiwadan batin, tauhid membebaskanjiwadari pengaruh kekuasaan orang lain, tauhid menumbuhkan keyakinan tentang rezeki, tauhid memberikan kehidupan yang baik, hakikat syirik dan anasir-anasirnya dan tauhid dan amarma'rufnahi munkar. Kedua: Hukum Islam Sumber hukum Islam, arkanul Islam, konsep thoharoh, konsep hukum, konsep keadilan, konsep syura, konsep jama'ah, konsep Jenayah, konsep sahsiyah, konsep muamalah, konsep mu'asyarah, Islam dan hukum universal, konsistensi dan fleksibiliti hukum Islam. Ketiga: Konsep Pengetahuan Islam: AlQur'an dan ilmu pengetahuan, hadis dan ilmu pengetahuan, ekonomi Islam, pengurusan Islam, konsep kesihatan dan keselamatan Islam, sains Islam, modenisasi Islam, tokoh saintis Islam, kemajuan sains Islam, sains dan materialisma, sains dan westemisma. Keempat: Sejarah Islam falsafah sejarah, sejarah dan kepentingan dakwah, sejarah dalam al Qur'an, sejarah rasul, sejarah sahabat, sejarah peradaban Islam, sejarah tokoh kontemporari Islam, sejarah konflik dalam Islam. Kelima: Etika Islam: Konsep ihsan, adab berbicara, adab mendengar, adab melihat, adab pergaulan (ibu bapa, sebaya, masyarakat, guru dan ulama), adab 
bertetangga, adab makan-minum, adab berpakaian, adab tidur, adab mandi, adab terhadap haiwan dan adab terhadap tumbuhan.

1. Untuk mengenal pasti tahap mental-kognitif Islam remaja yang melakukan salah laku

2. Untuk mengetahui pemerihalan taburan tahap mental kognitif Islam mengikut latar belakang pesalah laku remaja.

\section{METODE KAJIAN}

Kajian dijalankan secara tinjauan dengan menggunakan soal selidik sebagai instrumen kajian. Manakala persampelan kajian ini adalah berbentuk purposive randomsampling, hal ini dimaksudkan sampel diambil hanya pada cluster umur remaja dan secara rawak diambil untuk dijadikan responden kajian. Responden seramai 490 orang remaja yang berumur dalam lingkungan 13 hingga 22 tahun yang berada dalam pusat pemulihan dan dari latar belakang demografi yang berbeda telah dipilih. Bagi responden kajian yang tidak pandai membaca, enumerator telah membantu membacakan soal selidik dimaksud tanpa menerangkan secara terperinci maksud soal selidik, kerana keterangan yang panjang dari enumeratorakan menyebabkan tidak mendapat data sebenar tahap variable mental-kognitif dan psikososial remaja yang akan diukur. Lokasi kajian ini diambil dari empat negeri yaitu Terengganu, Kelantan, Melaka dan Perak. Pemilihan lokasi ini berdasarkan keperluan untuk mengambil responden lelaki dan perempuan. Maka responden perempuan diambil pada pusat pemulihan Melaka, Terengganu dan Kelantan, manakala responden lelaki diambil pada pusat pemulihan di Perak dan Melaka.

Kajian ini menggunakan satu set soal selidik yang terbagi kepada bagian latar belakang responden dan bagian skala-mental kognitif Islam (Khairil \& Khaidzir 2011). Tahap mental-kognitif Islam remaja diukur dengan menggunakan skala binariia itu jawaban 'ya' dan 'tidak', dimana jawaban 'ya' diberi nilai dua dan jawaban 'tidak' diberi nilai satu. Skala ini terdiri dari soalan positif dan negatif. Apabila soalan negatif dijawab pada pilihan 'ya' maka nilainya menjadi satu dan sebaliknya bila memberi jawapan tidak akan diberi nilai dua. Skala ini memiliki 174 item terdiri dari empat sub-skala seperti di Rajah 3.5 memperlihatkan domain Tauhid 21 item, hukum Islam 79 item, pengetahuan Islam 51 item dan sejarah Islam 23 item.

Indeks mental-kognitif Islam julat yang tinggi adalah skor 60 keatas. Manakala julat yang rendah adalah dibawah skor 60 kebawah. Pilihan jawaban mempunyai dua julat (binary) ya dan tidak. Kenyataan positif (seperti "keikhlasan dapat menyihatkan badan"). Bagi kenyataan negatif (seperti "tidak mengapa tidak percaya dengan adanya malaikat, yang penting percaya kepadaAllah SWT'). 
Data dianalisis menggunakan formula matematikal (Samsudin A.Rahim 2006) untuk mendapatkan skordomain mental kognitifIslam: Skor Indikator: $\left.\sum[\underline{\mathrm{M}} \underline{\underline{-M}}] \underline{\mathrm{M}}\right] \times 100$

$$
\mathrm{R}
$$

Skor domain: $\left.\bar{X}_{=} \sum \underline{\underline{\mathrm{M}}} \underline{\underline{\mathrm{M}}} \underline{\mathrm{Ms}}\right] \times 100$

SkorIndeks: $\quad \bar{X}_{\text {indeks }}=\frac{\Sigma \overline{\mathrm{x}} \text { domain }}{\mathrm{N} \text { domain }}$

Keterangan:

$\sum$ : jumlah skorindeks

M1: $\min$

Ms: skor minimum

$\mathrm{R}$ : range (skor maksimum tolak skorminimum)

100: skor tertinggi yang dianggarkan

\section{HASIL PENELITIAN}

\section{Domain Mental Kognitif Islam}

Meneru si rajah 1, menunjukkan domain yang terdapat didalam mental-kognitif Islam dan skor yang diperolehi. Skor-skor tersebut ialah tauhid (57.24), hokum Islam (57.71), Pengetahuan Islam (51.02) dan sejarah Islam (40.26). Indeks yang diperolehi untuk mental-kognitif Islam ialah 51.56.

Rajah 1 memperlihatkan bahwa skor domain mental-kognitif Islam yang paling rendah dicapai adalah sejarah Islam (40.21). Selanjutnya Pengetahuan Islam dan tauhid. Manakala hukum Islam (57.71) menempati skor yang tertinggi.

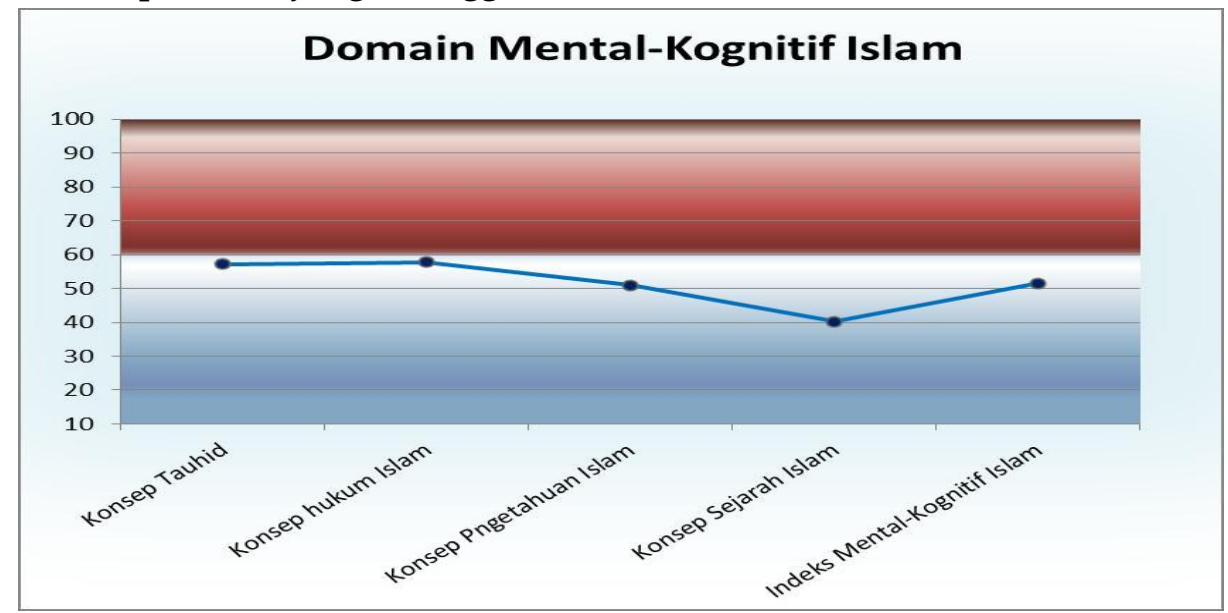

Rajah 1 Domain Mental-Kognitif Islam 


\section{Skor Umum Konstruk Mental-Kognitif Islam}

Berdasarkan rajah 2, menunjukkan konstruk yang terdapat didalam mental-kognitif Islam dan skor yang diperolehi. Skor yang diperolehi oleh konstruk tersebut ialah tauhid (57.24), keadilan (57.50), musyawarah (56.67), jemaah (50.00), jenayah (70.13), sahsiah (53.60), muamalah (66.67), hokum Islam (49.40), pengetahuan Islam (51.11), ekonomi Islam (49.44), pengurusan Islam (50.87), keselamatan dan kesihatan Islam (50.00), sains Islam (53.67) dan sejarah Islam (40.26).

Rajah 2 memperlihatkan bahwa skor konstruk mental-kognitif Islam yang paling rendah dicapai adalah sejarah Islam (40.26). selanjutnya adalah hokum Islam, ekonomi Islam, jemaah, keselamatan dan kesihatan Islam, pengurusan Islam, pengetahuan Islam, sahsiah, sains Islam, musyawarah, tauhid, keadilan muamalah. Manakala skor Jenayah (70.13) menempati skor yang tertinggi.

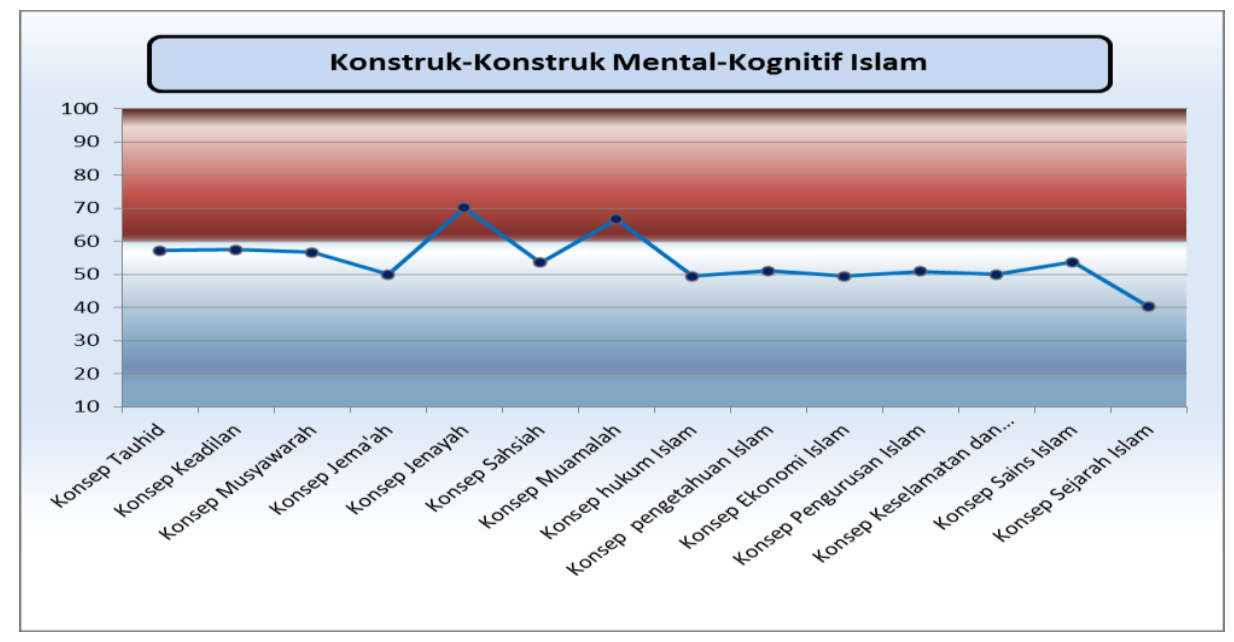

Rajah 2 Konstruk Mental-Kognitif Islam

Rajah 3, menunjukkan konstruk yang terdapat di dalam mentalkognitif Islam dan skor yang diperolehi berdasarkan jantina. Skor yang diperolehi bagi kumpulan lelaki dengan konstruk tersebut ialah tauhid (55.67), keadilan (55.10), musyawarah (57.67), jemaah (51.20), Jenayah (67.18), sahsiah (53.40), muamalah (65.22), hokum Islam (45.67), Pengetahuan Islam (50.55), ekonomi Islam (47.22), pengurusan Islam (48.22), keselamatan dan kesihatan Islam (47.67), sains Islam (53.83) dan sejarah Islam (42.52).

Manakala skor yang diperolehi bagi kumpulan perempuan dengan konstruk tersebut ialah tauhid (59.10), keadilan (60.30), musyawarah (55.67), jemaah (48.80), jenayah (74.73), sahsiah (53.40), muamalah (68.22), hokum Islam(51.53), pengetahuan Islam (51.55), ekonomi Islam 
(51.78), pengurusan Islam (54.13), keselamatan dan kesihatan Islam (53.83), sains Islam (54.75) dan sejarah Islam (37.30).

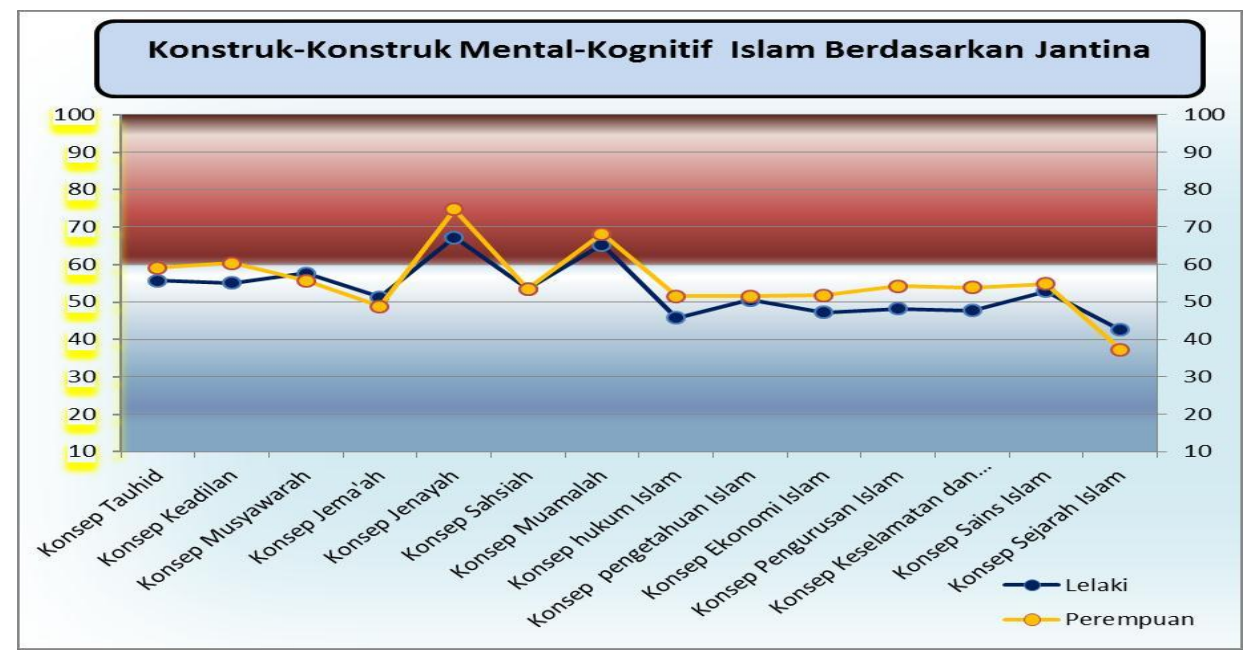

Rajah 3 Konstruk Mental-Kognitif Islam berdasarkan Jantina

Rajah 3 memperlihatkan bahawa responden lelaki dan perempuan sama-sama menempati skor terendah pada konstruk sejarah Islam. Pada konstruk ini skor perempuan (51.53) lebih tinggi berbanding lelaki (45.67). Demikian pula responden lelaki dan perempuan sama-sama menempati skor tertinggi pada konstruk konsep Jenayah. Pada konstruk ini skor perempuan (74.73) lebih tinggi berbanding lelaki (67.18). Secara umum skor perempuanlebih tinggi berbanding lelaki.

Berdasarkan rajah 4, menunjukkan konstruk yang terdapat di dalam mental-kognitif Islam dan skor yang diperolehi dengan jenis kesalahan. skor yang diperolehi bagi responden yang melakukan kesalahan seksual dengan konstruk tersebut ialah tauhid (58.04), keadilan (60.50), musyawarah (53.60), jemaah (49.40), jenayah (66.67), sahsiah (53.40), muamalah (59.89), hukum Islam (50.93), pengetahuan Islam (57.11), ekonomi Islam (50.67), pengurusan Islam (52.40), keselamatan dan kesihatan Islam (51.83), sains Islam (54.67) dan sejarah Islam (40.22).

Manakala skor yang diperoleh bagi responden yang melakukan kesalahan melibatkan dadah dengan konstruk tersebut ialah tauhid (57.00), keadilan (59.40), musyawarah (58.63), jemaah (50.00), jenayah (73.33), sahsiah (57.60), muamalah (70.33), hukum Islam (49.73), pengetahuan Islam (53.89), ekonomi Islam (49.78), pengurusan Islam (50.33), keselamatan dan kesihatan Islam (48.83), sains Islam (54.83) dan sejarah Islam (42.96).

Bagi jenis kesalahan mencuri skor yang diperolehi dengan konstruk tersebut ialah tauhid (57.00), keadilan (55.60), musyawarah (58.00), jemaah (54.40), jenayah (68.93), sahsiah (51.40), muamalah (64.11), hukum Islam 
(49.60), pengetahuan Islam (49.11), ekonomi Islam (49.33), pengurusan Islam (49.20), keselamatan dan kesihatan Islam (48.50), sains Islam (51.83) dan sejarah Islam (41.61). Skor yang diperolehi bagi responden yang melakukan kesalahan gangsterisme dengan konstruk tersebut ialah tauhid (55.47), keadilan (55.00), musyawarah (54.00), jemaah (46.40) jenayah (67.80), sahsiah (52.20), muamalah (65.89), hukum Islam (49.73), pengetahuan Islam (45.44), ekonomi Islam (45.67), pengurusan Islam (48.87), keselamatan dan kesihatan Islam (53.00), sains Islam (51.67) dan sejarah Islam (41.04).

Bagi jenis kesalahan luar kawalan skor yang diperolehi dengan konstruk tersebut ialah tauhid (61.47), keadilan (58.90), musyawarah (59.33), jemaah (47.20), jenayah (66.73), sahsiah (51.20), muamalah (69.56), hukum Islam(51.60), pengetahuan Islam (51.67), ekonomi Islam (51.56), pengurusan Islam (52.27), keselamatan dan kesihatan Islam (53.17), sains Islam (55.67) dan sejarah Islam (37.48).

Manakala skor yang diperolehi bagi responden yang melakukan kesalahan melibatkan dadah dengan konstruk tersebut ialah tauhid (57.00), keadilan (59.40), musyawarah (58.63), jemaah (50.00) jenayah (73.33), sahsiah (57.60), muamalah (70.33), hukum Islam (49.73), pengetahuan Islam (53.89), ekonomi Islam (49.78), pengurusan Islam (50.33), keselamatan dan kesihatan Islam (48.83), sains Islam (54.83) dan sejarah Islam (42.96).

Skor yang diperolehi bagi responden yang melakukan kesalahan lari dari rumah dengan konstruk tersebut ialah tauhid (58.05), keadilan (59.30), musyawarah (56.00), jemaah (47.20), jenayah (69.53), sahsiah (52.80), muamalah (68.00), hukum Islam (50.80), pengetahuan Islam (54.78), ekonomi Islam(50.67), pengurusan Islam (53.20), keselamatan dan kesihatan Islam (53.33), sains Islam (55.25) dan sejarah Islam (35.83).

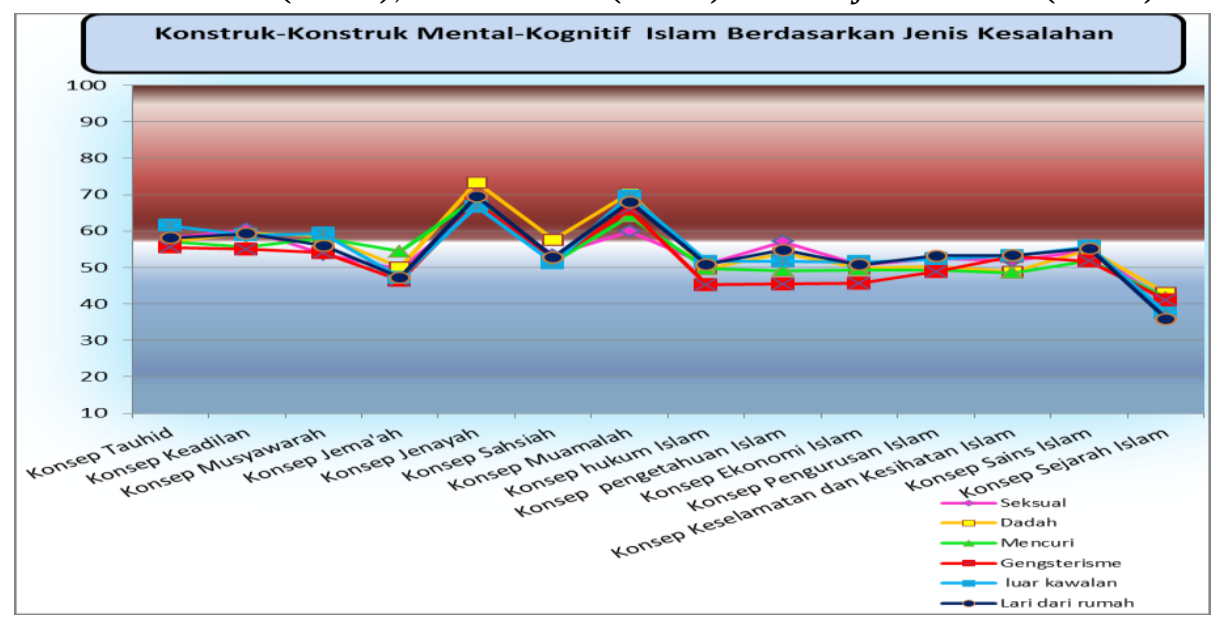

Rajah 4 Konstruk Mental-Kognitif Berdasarkan Jenis Kesalahan 
Rajah 4 memperlihatkan bahwa responden mengikut jenis kesalahan adalah sama-sama menempati skor terendah pada konstruk sejarah Islam. Pada konstruk ini skor terendah terdapat pada jenis kesalahan lari dari rumah (35.83). Demikian pula responden mengikut jenis kesalahan juga sama-sama menempati skor tertinggi pada konstruk konsep Jenayah. Pada konstruk ini skor jenis kesalahan dadah (73.33) menempati paling tinggi. Secara umum skor terendah adalah pada jenis kesalahan gangs terisma.

Berdasarkan rajah 5, menunjukkan konstruk yang terdapat di dalam mental-kognitif Islam dan skor yang diperolehi dengan tahap umur. Skor yang diperolehi bagi responden yang berumur $13-15$ tahun (remaja awal) dengan konstruk tersebut ialah tauhid (50.43), keadilan (45.70), musyawarah (45.67), jemaah (43.00), jenayah (59.73), sahsiah (45.20), muamalah (57.44), hukum Islam(40.00), pengetahuan Islam (40.00), ekonomi Islam (43.00), pengurusan Islam (43.53), keselamatan dan kesihatan Islam (45.00), sains Islam (45.33) dan sejarah Islam (35.61).

Manakala skor yang diperolehi bagi responden yang berumur16 18 tahun (remaja pertengahan) dengan konstruk tersebut ialah tauhid (57.95), keadilan (58.60), musyawarah (56.50), jemaah (50.60), jenayah (72.20), sahsiah (55.00), muamalah (67.67), hokum Islam (49.73), pengetahuan Islam (51.22), ekonomi Islam (50.22), pengurusan Islam (52.07), keselamatan dan kesihatan Islam (50.33), sains Islam (54.67) dan sejarah Islam (39.96).

Bagi responden yang berumur 19-22 tahun (remaja akhir) skor yang diperoleh dengan konstruk tersebut ialah tauhid (57.71), keadilan (58.80), musyawarah (59.50), jemaah (51.00), jenayah (71.60), sahsiah (53.20), muamalah (67.67), hukum Islam (51.00), pengetahuan Islam (53.22), ekonomi Islam (49.67), pengurusan Islam (50.53), keselamatan dan kesihatan Islam (50.67), sains Islam (54.00) dan sejarah Islam (41.52).

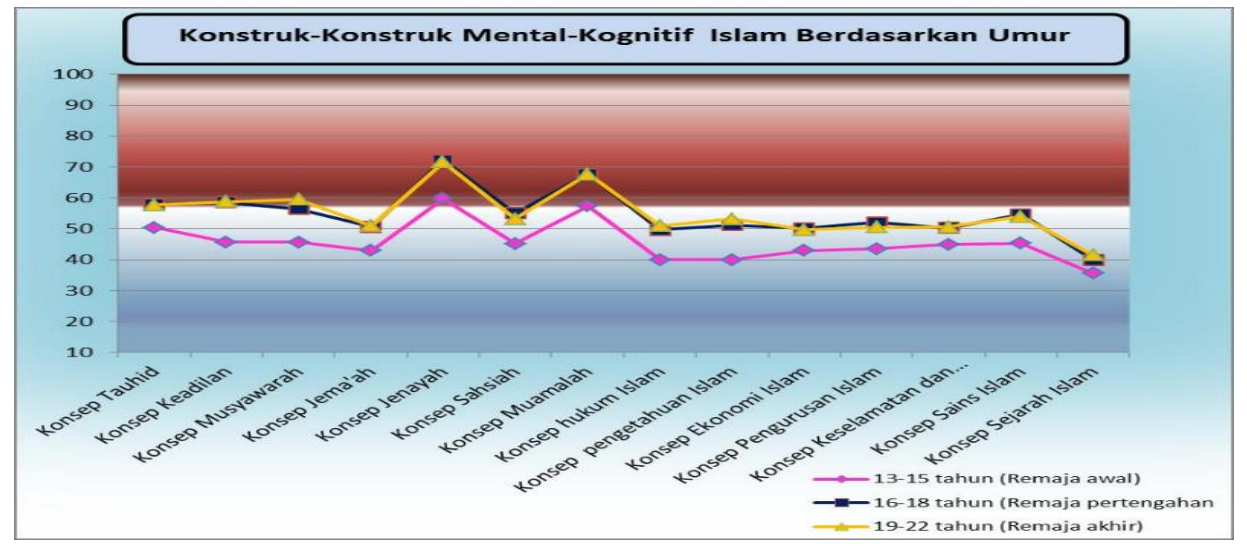

Rajah 5 Konstruk Mental-Kognitif Islam Berdasarkan umur 
Rajah 5 memperlihatkan bahwa responden mengikut umur adalah sama-sama menempati skor terendah pada konstruk sejarah Islam. Pada konstruk ini skor terendah terdapat pada tahap umur 13-15 tahun (35.61). Demikian pula responden mengikut umur juga sama-sama menempati skor tertinggi pada konstruk konsep Jenayah. Pada konstruk ini skor tahap umur 16-18 tahun (72.20) menempati paling tinggi. Secara umum skor terendah pada konstruk Mental-kognitif Islam adalah dalam kumpulan umur 13-15 tahun sebagai yang disebut remaja awal.

\section{PEMBAHASAN}

Secara umum profil mental kognitif Islam diukur dengan skor di bawah 60 adalah aras rendah dan 60 ke atas adalah aras tinggi. Kajian ini remaja berisiko berada pada paras skor yang rendah (51.56). Mentalkognitif yang menggambarkan cara berfikir bathiniyyah (mental) remaja adalah suatu konsep penting yang akan menetukan sikap dan tingkahlaku remaja dalam persekitaran yang penuh dengan pelbagai gejala sosial. Mental kognitif Islam yang jauh adalah suatu aspek yang merupakan cara pandang kehidupan seorang muslim dari sudut agama yang diyakini secara mendalam dan lebih cenderung lebih mengutamakan dalaman daripada simbol luaran. Indikator-indikator yang terdapat dalam pengukuran mentalkognitif Islam ini dibina secara khas untuk melakukan penilaian. Rendahnya aras mental kognitif Islam remaja adalah salah satu yang boleh dijadikan indikator mengapa terjadinya tingkah laku anti sosial dalam kalangan remaja.

Pengukuran mental kognitif ini dibina bertujuan untuk menggambarkan pemikiran dan amalan keagamaan yang bersifat abstrak bukan yang kongkrit. Salah satu contoh item "boleh berpelukan dan bercumbu asal tidak berzina". Item ini adalah bersifat abstrak untuk mengukur kecendrungan tingkah laku zina, dan bukan mengukur hukum berzina. Bagi seseorang yang befikiran kongkrit akan menjawab ya, kerana mereka akan terpengaruh dengan hukum perilaku berzina. Namun bagi mereka yang berfikiran abstrak mereka akan menjawab tidak, kerana mereka akan mendahulukan kejadian dan hukum sesuatu perkara bergantung pada sebab dan akibat (kausaliti). Kebanyakan remaja berisiko dalam kajian ini menjawab ya. Seperti item" boleh menjual arak kepada orang bukan Islam", kebanyakan remaja dalam kajian ini menjawab ya. Jawaban ini menunjukkan betapa rendahnya mental kognitif remaja dalam menilai hukum halalnya suatu perbuatan. Mereka lebih mendahulukan hukum haram meminum arak, dan mereka abaikan hukum menjualnya. Pada tradisi pendidikan pengajaran Islam, kurikulum pendidikan Islam hanya mengajar tentang hukum halal sesuatu perbuatan ataupun zat, namun dari segi perbuatan lainnya diabaikan. Seperti yang kita ketahui, hukum meminum arak dan menjual arak untuk orang Muslim adalah 
haram. Namun menjual arak untuk orang yang bukan muslim tidak mendapat penjelasan yang baik. Seakan-akan zat haram hanya dilarang untuk orang Islam, padahal hukum yang ditetapkan Allah adalah untuk semua manusia. Setiap orang Islam wajib melarang orang lain melakukan perbuatan haram, dan hasil penjualan zat haram hukumnya adalah haram serta membantu menyediakan benda haram hukumnya adalah haram. Pemahaman holistik ini membawa impak sosial yang luas untuk mencegah berlakunya gejala sosial, khususnya gejala sosial dalam kalangan remaja Islam.

Rendahnya aras mental kognitif remaja Islam membawa makna yang sangat signifikan tentang pemahaman Islam yang syumul dalam kalangan remaja berada dalam keadaan kritikal. Aktiviti jenayah akan terus berlaku dalam kalangan remaja, selagi aras mental kognitif Islam tidak ditingkatkan secepat mungkin.

Keyakinan sebagai salah satu asas penting mental kognitif Islam untuk memperbaiki sikap dan tingkah laku manusia, khususnya bagi para remaja. Keyakinan ini dapat mematahkan pertumbuhan pemikiran yang materialisma dalam kalangan remaja, dan menyuburkan semangat bekerja dan berusaha. Allah SWT mewajibkan kita berusaha namun menjatuhkan hukum haram meyakini apa yang diusahakan merupakan pemikiran yang bagus. Pola berfikir ini adalah bentuk kesejahteraan psikologi yang berlandaskan Islam. Tauhid sebagai asas utama Psikologi Islam tidak jumud, namun ia dapat mencerdaskan akal manusia agar tidak dibelenggu oleh pemikiran materilis-positivisma, sebagai pemacu tingkah laku yang cenderung ke arah anti sosial.

Ketauhidan yang benar dan lurus akan menerangi kehidupan masyarakat dengan pancaran cahayanya, sekaligus memberi pengaruh luar biasa terhadap dimensi kehidupan sama ada dalam pemikiran, pemahaman, perasaan, akhlak mahupun aturan. Keimanan adalah proses kejiwaan yang berkaitan dengan dimensi rohani, meliputi akal, keinginan dan perasaan manusia. (Yusuf, Muhammad al-Sayyid dan Durrah, Ahmad. 2008) Qardawi (2007) mengatakan jika dikaitkan dengan individu dan masyarakat, iman merupakan benteng yang mampu menjaganya dari kebinasaan dan pelbagai marabahaya. Kehidupan yang terlepas daripada iman adalah kehidupan yang tidak mengandung kebajikan, kemuliaan dan peri kemanusiaan. Unsur keburukan, kerosakan, dan marabahaya akan subur di dalam jiwa. Individu atau masyarakat yang hidup tanpa iman dan agama bagaikan anai-anai yang ditiup angin; sangat rapuh, lemah, hilang tujuan hidup, terasing, mudah terombang ambing kesana kemari, sentiasa berasa tidak tenang, tidak memiliki halatuju hidup yang jelas, sentiasa berasa bimbang, serta tidak memahami hakikat diri dan rahsia dirinya diciptakan.

Oleh itu dalam menghadapi fenomena ini maka keluarga Keluraga adalah kumpulan sosial yang paling kecil dalam masyarakat bagi 
pembentukan mental kognitif Islam remaja. Bagi setiap keluarga (suami, isteri, dan anak-anak) mempunyai proses sosialisasi untuk dapat memahami, menghargai budaya yang berlaku dalam masyarakat. Pendidikan dalam keluarga adalah sangat penting dan merupakan tonggak dasar bangunan watak untuk kanak-kanak. Terutama pendidikan penenaman nilai nilaui agama sebagai dasar mental kognitif remaja yang akan mengatur cara berfikir remaja.

\section{DAFTAR PUSTAKA}

Cattell, R.B.(1963). Theory of fluid and crystallized intelligence: A critical experiment.Journal of Educational Psychology54, 1-22.

Fuad Amsyari. (1995). Islam Kaaffah: Tantangan social dan aplikasinya di Indonesia. Jakarta: Gema Insani press.

Halstead,B. (1992).Young people asvictims ofviolence. Tasmania: National clearing house for youth studies.

Hamzah Ya'qub. (1983). Etika Islam pembinaan akhlakul karimah. Bandung: CV. Diponegoro.

Kementerian Belia dan Sukan. (2015). Dasar Belia Malaysia. Malaysia: KBS.

Khaidzir Hj. Ismail \& Khairil Anwar. (2011). Psikologi Islam: Suatu Pendekatan Psikometrik Remaja Berisiko (Islamic Psychology: An Approach to Psychometric For At-Risk Adolescence). Jurnal E-Bangi 6(1): 77-89.

Khaidzir Hj. Ismail \& Khairil Anwar. (2005). Keperibadian dan Tingkah Laku Kriminal di Kalangan Remaja: Suatu Perspektif Psikologi Perkembangan. ANIMA Indonesian Psychological Journal 20:313329.

Khaidzir Hj.Ismail dan Khairil Anwar. (2009). Psikologi Islam: Falsafah, Teori dan Aplikasi. Kuala Lumpur: Institut Islam Hadhari \& IBook Publication.

Khaidzir Hj. Ismail. (2007). Profile of At-Risk Female Adolescent: A Case Study in Selangor. INMIND, National.

Khairil Anwar dan Khaidzir Hj. Ismail. (2009). Tahap Mental-Kognitif Islam Dan Pengaruhnya Ke Atas Identiti Keagamaan Remaja Beresiko. Prosiding Persidangan Psikologi Malaysia 2009. Bangi: Universiti Kebangsaan Malaysia.

Khairil Anwar dan Khaidzir Hj. Ismail. (2009). Profil Mental-Kognitif dan Psiko-Sosial Islam Di Kalangan Remaja Beresiko. Prosiding International Seminar of Islamic though, Bangi Universiti Kebangsaan Malaysia

Khaidzir Hj. Ismail, Khairil Anwar \& Hanina H. Hamsan. (2011). Measurement of Self-Esteem: Comparison between the 
Constructs of West and Islam. International Journal of Humanities and SocialScience 1(13): 170-196.

Saifuddin Azwar. (1996). Psikologi Inteligensi. Yogyakarta: PustakaBelajar Samsudin A. Rahim et al. 2006. Indeks Belia Malaysia. Putra Jaya: Institut Penyelidikan Pembangunan Belia Malaysia (IPPBM).

Yahya, Harun. (2002). Moralitas Al-Qur'an; Solusi Atas Segala Persoalan Umat Manusia. Jakarta; Rabbani Press.

Yusuf, al-Sayyid, Muhammad \& Durrah, Ahmad. (2008). Pustaka Pengetahuan al-Qur'an: IlmuPengetahuan. Volume ke-6. Jakarta: PT. Rehal Republika.

Zainah Ahmad Zamani, Rohany Nasir, Asmawati Desa, Rozainee Khairudin, Fatimah Yusooff, Siti Hajar Mohamad Yusoff. (2013). Kefungsian keluarga, pengherotan kognitif dan resilien dalam kalangan klien Cure and Care Rehabilitation Centre (CCRC) dan Klinik Cure and Care (C\&C). Jurnal Psikologi Malaysia, 27:137-149. 